\title{
GENETIC IDENTIFICATION OF WHITE-HANDED GIBBONS (Hylobates Lar) IN CAPTIVITY
}

\author{
NOR RAHMAN AIFAT AND BADRUL MUNIR MD-ZAIN* \\ Department of Biological Sciences and Biotechnology, Faculty of Science and Technology, Universiti Kebangsaan Malaysia, \\ 43600, Bangi, Selangor.
}

*Corresponding author: abgbadd@ukm.edu.my

Submitted final draft: 18 August $2020 \quad$ Accepted: 25 August 2020

http://doi.org/10.46754/jssm.2021.06.023

\begin{abstract}
White-handed gibbons exhibit different morphological variants describing five recognized subspecies, which are Hylobates lar lar, Hylobates lar carpenteri, Hylobates lar entelloides, Hylobates lar vestitus, and Hylobates lar yunnanensis. Several systematic gibbon studies are available, but focus only on interspecific variation. In this study, we used molecular systematics to genetically identify captive white-handed gibbon subspecies. About 674 base pairs of the mitochondrial Cytochrome $b$ (Cyt $b$ ) gene were analyzed from 12 unrelated captive lar gibbons, using species-specific primers with published $H$. lar GenBank sequences. Phylogenetic trees were reconstructed using MEGA 7. Tree topology indicates that two individuals, a white-handed gibbon from Malaysia's National Zoo and Taiping Zoo each, grouped together with reference to a subspecies from Thailand, namely H. l. carpenteri. Other white-handed gibbons from zoos and rescue centers had grouped together with the larger H. l. lar clade. The H. l. carpenteri individuals in our study were possibly introduced through gibbon trafficking or translocation from unknown sources in Thailand. Cyt $b$ in white-handed gibbons' genetic identification effectively portrays the subspecies' differentiation. Genetic identification of primates in captivity is crucial, especially when considering primate translocations and captive management decisions.
\end{abstract}

Keywords: White-handed gibbon, Hylobates lar, cytochrome b, genetic identification, captive.

\section{Introduction}

White-handed gibbons (Hylobates lar) are found in most Southeast Asian countries, including Laos, Myanmar, Thailand, Malaysia (Peninsular Malaysia), Indonesia (Sumatra), and in the Yunnan region in China (Woodruff et al., 2005). This species' distribution spans approximately $2,200 \mathrm{~km}\left(22^{\circ}\right.$ latitude). Due to their wide distribution ranges, white-handed gibbons might differ morphologically between the five recognized subspecies. The five subspecies of $H$. lar include: H. l. lar (Peninsular Malaysia), H. l. carpenteri (East Burma, West Laos and northern Thailand), H. l. entelloides (Southeast Burma, central and southern Thailand), H. l. vestitus (northern Sumatra) and H. l. yunnanensis (southwest Yunnan) (Corbet \& Hill, 1992;
Groves, 2001; Brandon-Jones et al., 2004; Geissmann, 2005; Roos et al., 2014). According to Groves (2001), and Mootnick (2006), these five subspecies exhibit different morphological characteristics (Table 1).

Systematic relationships in gibbons are still controversial. Previous investigations on the chromosomal, morphological, and behavioral features of gibbons have been utilized to attempt to resolve this. Garza and Woodruff (1992) reported mitochondrial Cytochrome $b$ (Cyt $b$ ) variations in Hylobates. Other investigators also utilized partial mitochondrial genes to study interspecific and intergeneric differences in the Hylobatidae family (Roos \& Geissmann, 2001; Takacs et al., 2005; Chatterjee, 2006; Meyer et al., 2012; Matsudaira et al., 2013). 
Table 1: Morphological characteristics of five $H$. lar subspecies

\begin{tabular}{ccl}
\hline No & \multicolumn{1}{c}{ Subspecies } & \multicolumn{1}{c}{ Morphological characteristic } \\
\hline 1. & H. l. lar & $\begin{array}{l}\text { Medium brown or dark chocolate brown in the dark form, with a } \\
\text { lighter torso and darker legs }\end{array}$ \\
2. & H. l. carpenteri & $\begin{array}{l}\text { Brownish charcoal in the dark form and creamy white. In the light } \\
\text { form, white buff in color } \\
\text { Black or black brown in the dark form. Honey colored in the light } \\
\text { form with darker legs } \\
\text { 3. }\end{array}$ H. l. entelloides \\
4. & H. l. vestitus & $\begin{array}{l}\text { Typically, light brown with no dark form. Lower back is pale with a } \\
\text { brown head, ventrum, and limbs } \\
\text { Light hair with a dark brown or red brown pubic region }\end{array}$ \\
5. & H. l. yunnanensis &
\end{tabular}

Chan et al. (2010) conducted a study based on mitochondrial genome sequences to reconstruct the phylogenetic relationships and reveal the evolutionary patterns of divergence events in the gibbon evolutionary history. By using more than $15 \mathrm{~kb}$ sequences of mtDNA genome, which represent 11 species belonging to three genera - Hylobates, Nomascus, and Symphalangus they recovered a well-supported phylogeny of the Hylobates gibbons. The divergence time estimates suggest a much more rapid speciation process in Hylobates, compared to Nomascus. To analyze the relationships between the gibbon genera in more detail, Veeramah et al. (2015) conducted a second-generation whole genome sequence analysis. Their findings support the hypothesis that all four gibbon genera (Nomascus, Symphalangus, Hoolock, and Hylobates) diverged around the same time.

In Malaysia, genetic studies on this endangered small ape, especially in captivity, are lacking. Molecular studies are required to genetically identify gibbons of unknown origin. According to Chan et al. (2012), natural hybridization of $H$. lar and $H$. pileatus was reported in Khao Yai National Park, Thailand. Subspecies identification through genetic approaches is required to prevent this from occurring in captivity, as hybridization of different species and subspecies may affect gene flow (Chan et al., 2012). Including genetic information in captive management programs is crucial for determining the correct subspecies, and will support the translocation of various gibbons to their original distribution ranges. Mitochondrial DNA is a valuable marker for examining the systematic relationships and genetic variation at a species and subspecies level (Md-Zain et al., 2010; Zainudin et al., 2010; Rosli et al., 2011; Abdul-Latiff et al., 2019). Md-Zain et al. (2010) used partial Cyt $b$ gene sequences to determine the molecular phylogenetic status of Horsfield's tarsier, among Malaysian primates. Based on tree topologies, three main clades were identified containing primitive primates, Old World Monkeys, and Anthropoids. In this study, we report the effectiveness of the Cyt $b$ locus in identifying captive white-handed gibbons at a subspecies level.

\section{Material and methods}

Fecal samples were collected from zoological parks (Melaka Zoo, National Zoo, and Taiping Zoo) and the Rescued Point (RP), through noninvasive sampling. We collected faecal samples from 12 captive gibbons of unknown subspecies classification (Table 2). Samples were labeled and stored in absolute ethanol (99\%). DNA was extracted from $0.5-1.0 \mathrm{~g}$ feces, using the InnuPREP Stool DNA Kit (Analytik Jena, Germany), following the manufacturer's protocol (Md-Zain et al., 2019).

An approximate 674 base pair (bp) region of the Cyt $b$ gene was amplified through PCR using species-specific primers. Primers were designed specifically for this species to avoid 
Table 2: List of gibbon samples and DNA sequences from GenBank

\begin{tabular}{|c|c|c|c|c|}
\hline No & Label & Species & Location / Source & Origin \\
\hline 1 & ARHLC528 & Hylobates lar & $\mathrm{RP}$ & Unknown \\
\hline 2 & ARHLM537 & Hylobates lar & Melaka Zoo & Captive born, Melaka Zoo \\
\hline 3 & ARHLM538 & Hylobates lar & Melaka Zoo & Captive born, Melaka Zoo \\
\hline 4 & ARHL568 & Hylobates lar & $\mathrm{RP}$ & Unknown \\
\hline 5 & ARHL569 & Hylobates lar & $\mathrm{RP}$ & Unknown \\
\hline 6 & $\mathrm{ZN} 1$ & Hylobates lar & National Zoo & Unknown \\
\hline 7 & $\mathrm{ZN} 2$ & Hylobates lar & National Zoo & Unknown \\
\hline 8 & ZN3 & Hylobates lar & National Zoo & Unknown \\
\hline 9 & $\mathrm{ZN} 4$ & Hylobates lar & National Zoo & Unknown \\
\hline 10 & ZN5 & Hylobates lar & National Zoo & Unknown \\
\hline 11 & ZT6 & Hylobates lar & Taiping Zoo & Unknown \\
\hline 12 & ZT7 & Hylobates lar & Taiping Zoo & Unknown \\
\hline 13 & GU321325.1 & $\begin{array}{l}\text { Hylobates lar } \\
\text { carpenteri }\end{array}$ & GenBank & Thinh et al. (2010) \\
\hline 14 & GU321327.1 & $\begin{array}{l}\text { Hylobates lar } \\
\text { entelloides }\end{array}$ & GenBank & Thinh et al. (2010) \\
\hline 15 & NC002082 & $\begin{array}{l}\text { Hylobates lar } \\
\text { entelloides }\end{array}$ & GenBank & Arnason et al. 1996 \\
\hline 16 & GU321329.1 & Hylobates lar vestitus & GenBank & Thinh et al. (2010) \\
\hline 17 & NC014042 & Hylobates agilis & GenBank & Matsudaira \& Ishida (2010) \\
\hline 18 & GU321283.1 & $\begin{array}{l}\text { Symphalangus } \\
\text { syndactylus }\end{array}$ & GenBank & Thinh et al. (2010) \\
\hline 19 & GU321284.1 & $\begin{array}{l}\text { Symphalangus } \\
\text { syndactylus }\end{array}$ & GenBank & Thinh et al. (2010) \\
\hline 20 & GU321285.1 & $\begin{array}{l}\text { Symphalangus } \\
\text { syndactylus }\end{array}$ & GenBank & Thinh et al. (2010) \\
\hline 21 & NC001646 & Pongo pygmaeus & GenBank & Horai et al. (1992) \\
\hline
\end{tabular}

contamination related to the nuclear insertion of mitochondrial pseudogenes (numts) (Aifat et al., 2016; Abdul-Latiff et al., 2017). The primer sequences are as follows: HL2626_F 5'- TTT TAG CCA TAC ACT ACA CA -3' and HL0303_R 5'- GAA ATA TCA TGC TTT GCT GT -3'. Amplification was carried out using the MyTaq ${ }^{\text {TM }}$ Red Mix from Bioline, in a total volume of $25 \mu \mathrm{l}$, containing: $12.5 \mu 1 \mathrm{MyTaq}^{\mathrm{TM}}$ Red Mix, $1.0 \mu \mathrm{l}$ of each $20 \mu \mathrm{M}$ primer (forward and reverse), $3.0 \mu \mathrm{l}$ DNA template, and $\mathrm{ddH}_{2} \mathrm{O}$ was added to reach the final volume. PCR conditions for all amplifications were identical and consisted of: pre-denaturation at $95{ }^{\circ} \mathrm{C}$ for
$3 \mathrm{~min}$; followed by 30 cycles of denaturation at $95^{\circ} \mathrm{C}$ for $15 \mathrm{sec}$, annealing at $46.5^{\circ} \mathrm{C}$ for 30 sec, and elongation at $72^{\circ} \mathrm{C}$ for $10 \mathrm{sec}$; followed by final elongation at $72^{\circ} \mathrm{C}$ for $10 \mathrm{~min}$. PCR products were observed on a $1.5 \%$ agarose gel in a $1 \mathrm{X}$ TAE Buffer.

PCR products were purified using the innuPREPDOUBLE pure Kit (Analytik Jena, Germany), and sent to Apical Scientific Sdn. Bhd, Malaysia, for sequencing. DNA sequences were analyzed using BioEdit software v7. 2. 3 (Hall, 1999), and MEGA 7 (Tamura et al., 2013). The GenBank BLASTn application 
was used to evaluate the DNA quality and authenticity obtained from both primer reactions (Md-Zain et al., 2018). DNA sequences were aligned using ClustalW, and visually adjusted. Sequences were manually edited, to eliminate poorly aligned positions and divergent regions, using BioEdit (Karuppannan et al., 2019). Nine sequences were obtained from GenBank, four of which belonged to H. lar (H. l. entelloides, $H$. l. carpenteri and H. l. vestitus) (Arnason et al., 1996; Thinh et al., 2010), one to H. agilis (Matsudaira \& Ishida, 2010), and three to Symphalangus syndactylus (Thinh et al., 2010). Pongo pygmaeus was used as an outgroup (Horai et al., 1992). S. syndactylus is one of the species in the family Hylobatidae, which is distributed in Malaysia. The purpose of including Hominoidea is to resolve the tree of the family Hylobatidae.

Phylogenetic trees were constructed based on two different criteria, namely distance-based (Neighbor-Joining, NJ) and character-based (Maximum Parsimony, MP), using PAUP 4.0 (Rosli et al., 2011; Md-Zain et al., 2019). We decided to reconstruct a Bayesian tree, however, it portrayed the same morphology as NJ and MP. Thus, both phylogeny trees were maintained. Both phylogenetic trees were constructed with 1,000 bootstrap replications to obtain bootstrap confidence levels. Haplotype relationships of H. lar groups in captivity, with sequences from GenBank, were constructed using DnaSP v6 under the assumption that two randomly drawn haplotypes were unlikely to have occurred from more than one mutational step (Abdul-Latiff et al., 2019). A minimum-spanning network (MSN) was generated to portray the relationships among haplotypes, using Network 5 (Zainudin et al., 2010; Mohd-Yusof et al., 2020).

\section{Results}

All 12 gibbon samples were successfully amplified for the 674bp partial Cyt $b$ region. The Cyt $b$ sequence alignment of the gibbons (genus Hylobates), was characterized by 69 variable sites, 17 of which were parsimonyinformative sites. If the $H$. agilis sequence was excluded, the number of parsimony-informative sites was 12 . The NJ phylogeny tree (Figure 1) was generated using the Kimura-2-Parameter, with 1,000 bootstrap replications. The NJ tree topology exhibited two clades that distinguished sampled gibbons and siamang gibbons, with $100 \%$ bootstrap support. Two major clades separated the sample gibbons. A monophyletic clade was formed, comprising $H$. l. vestitus, $H$. l. entelloides, $H$. l. carpenter, and an unknown subspecies from captivity that clearly separated from $H$. agilis, with $99 \%$ bootstrap support. In the $H$. lar clade, $H$. l. vestitus was the first to diverge from other gibbons. Remaining individuals formed two subclades. The first subclade solely contained $H$. l. entelloides and the second subclade was further diverged into two additional groups with $79 \%$ and $71 \%$ bootstrap support. H. l. carpenteri grouped together with captive gibbons from the National Zoo (ZN4) and Taiping Zoo (ZT2), with low bootstrap support (56\%). Other captive gibbons formed a monophyletic clade with $71 \%$ bootstrap support.

The most parsimonious (MP) tree (Figure 2) had a Consistency Index, CI $=0.673077$; Retention Index, RI $=0.738462$, and tree length $=126$. The general clade formation in the MP tree resembled the NJ tree topology. Gibbons were clearly distinguished from siamang gibbons, but with low bootstrap support. Clade formation remained similar to the $\mathrm{NJ}$ tree topology for the 12 captive gibbons. Pairwise genetic distances of the partial Cyt $b$ region for all gibbon sequence data was calculated using the Kimura-2-Parameter model (Table 3). The highest genetic distance of 0.023 was recorded between $H$. $l$. vestitus and $H$. lar from the Melaka Zoo. 
Table 3: Pairwise genetic distances calculated using the Kimura-2-Parameter model

\begin{tabular}{lccccccc}
\hline \multicolumn{1}{c}{ Locality/subspecies } & $\mathbf{1}$ & $\mathbf{2}$ & $\mathbf{3}$ & $\mathbf{4}$ & $\mathbf{5}$ & $\mathbf{6}$ & $\mathbf{7}$ \\
\hline [1] Rescue Point & - & & & & & & \\
[2] Melaka Zoo & 0.006 & - & & & & & \\
[3] National Zoo & 0.006 & 0.008 & - & & & & \\
[4] Taiping Zoo & 0.005 & 0.007 & 0.005 & - & & \\
[5] H. l. entelloides & 0.014 & 0.016 & 0.015 & 0.013 & - & \\
[6] H. l. carpenteri & 0.007 & 0.009 & 0.007 & 0.004 & 0.014 & - & \\
[7] H. l. vestitus & 0.021 & 0.023 & 0.021 & 0.018 & 0.022 & 0.020 & - \\
\hline
\end{tabular}

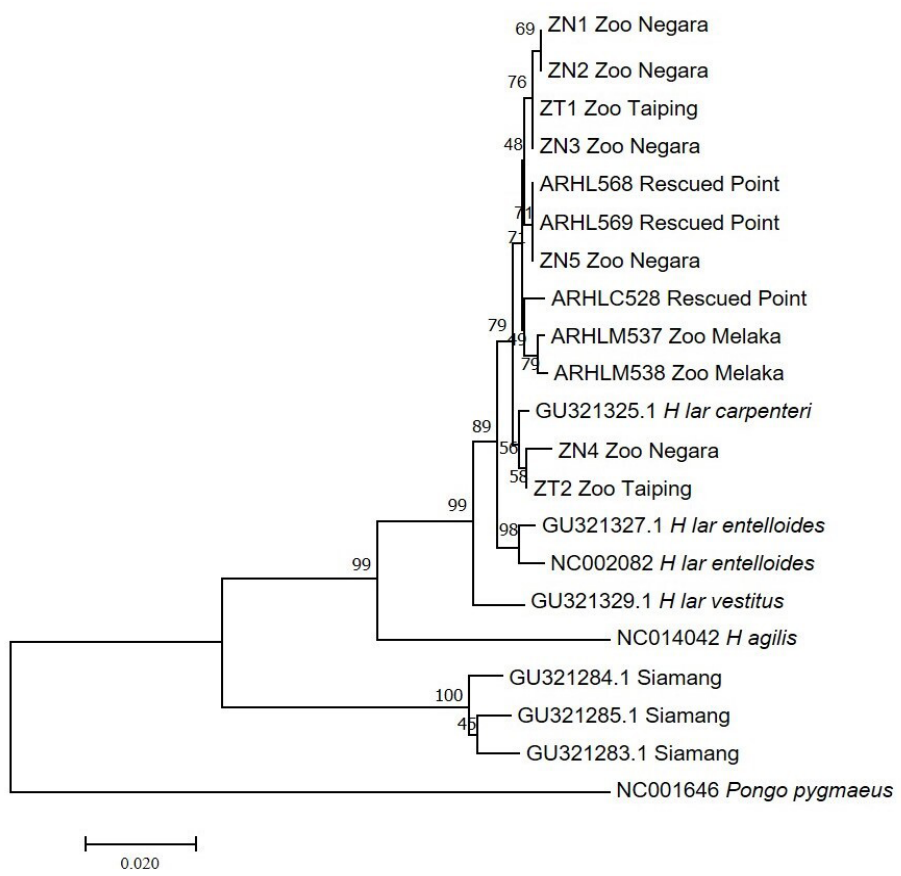

Figure 1: NJ phylogenetic tree. Bootstrap values are indicated above branches

Haplotype analyses of the Cyt $b$ region successfully yielded 12 haplotypes with a haplotype diversity $(\mathrm{Hd})$ of 0.9583 (Table 4). Captive $H$. lar yielded 8 haplotypes, comprising Hap 1 to Hap 8. Hap 1 represented a single individual from the rescue center. Hap 2 and Hap 3 represented individual haplotypes from the Melaka Zoo. Hap 4 was shared between individuals from the rescue center and Negara Zoo. Hap 5 and Hap 7 represented individuals from the National Zoo. Hap 6 was shared between individuals from the National Zoo and Taiping Zoo. Hap 8 was represented by a single individual from Taiping Zoo. The other haplotypes were represented by each of the $H$. lar subspecies, namely $H$. l. entelloides (Hap 9 and Hap 10), H. l. carpenteri (Hap 11), and H. l. vestitus (Hap 12). The haplotype MSN visualized $H$. lar in captivity and showed that Hap 7 and Hap 8 were closer to H. l. carpenteri, with at least four mutational steps. Shared haplotypes were clearly indicated on the MSN diagram (Figure 3), further supporting the genetic relationships exhibited by the NJ and MP phylogenetic trees. The MSN illustrates haplotype relationships in which haplotype was grouped based on where the samples are from, thus, there are National Zoo, Taiping Zoo and RP. 


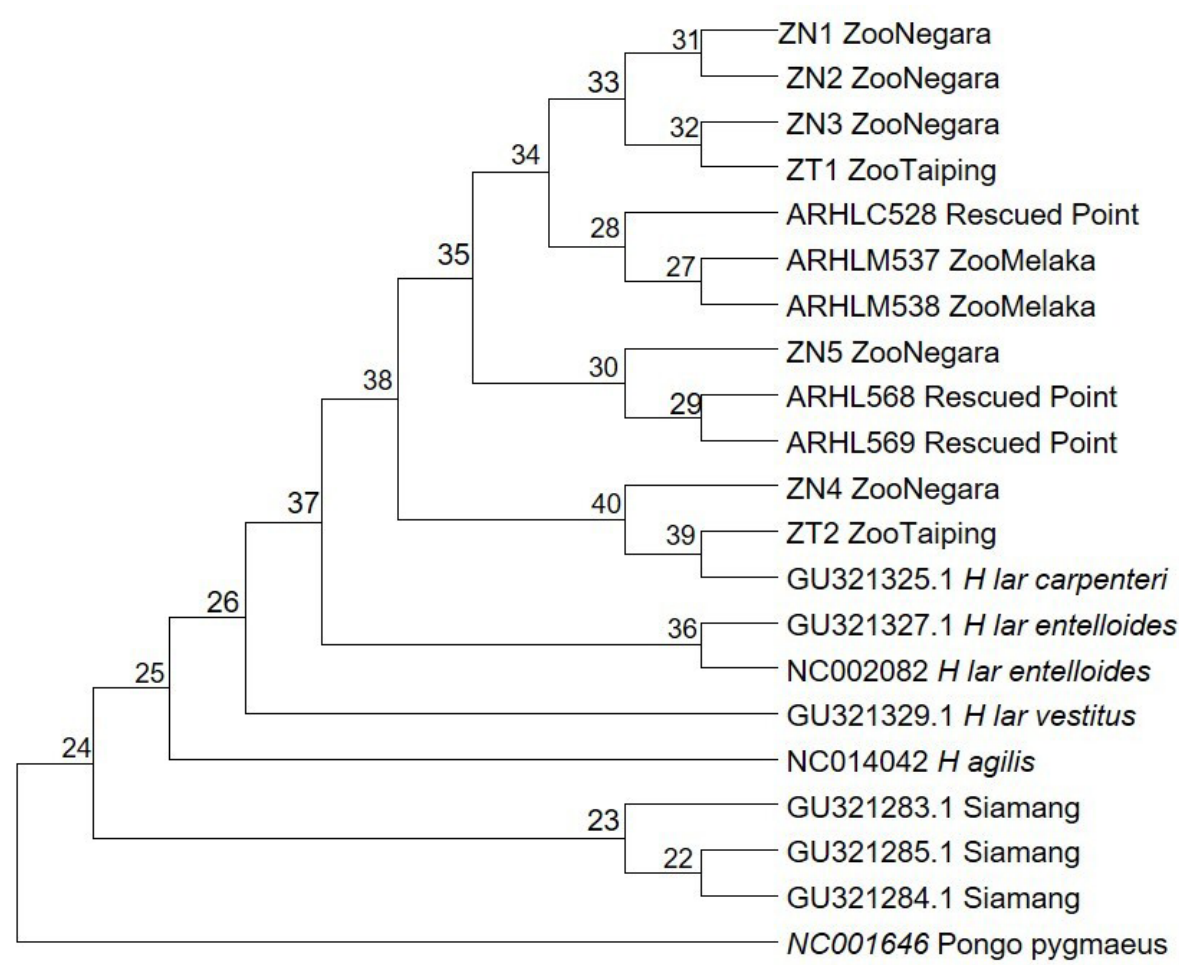

Figure 2: MP phylogenetic tree generated with tree-bisection-reconnection swapping, heuristic searching, and 1,000 bootstrap replications

Table 4: Defining haplotypes with segregating sites in the 674 bp Cyt b sequences

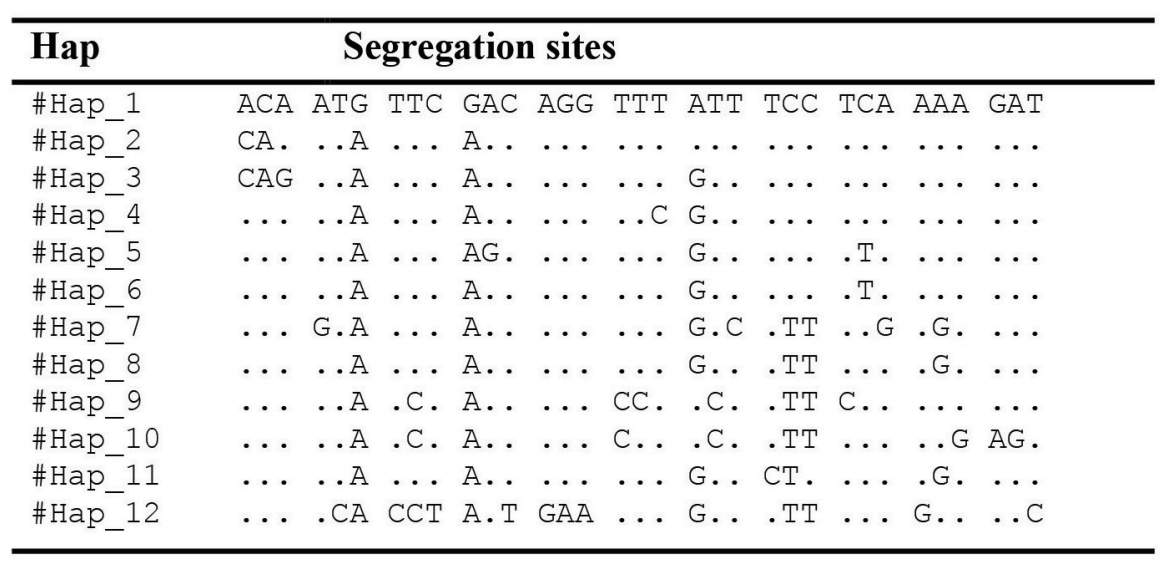



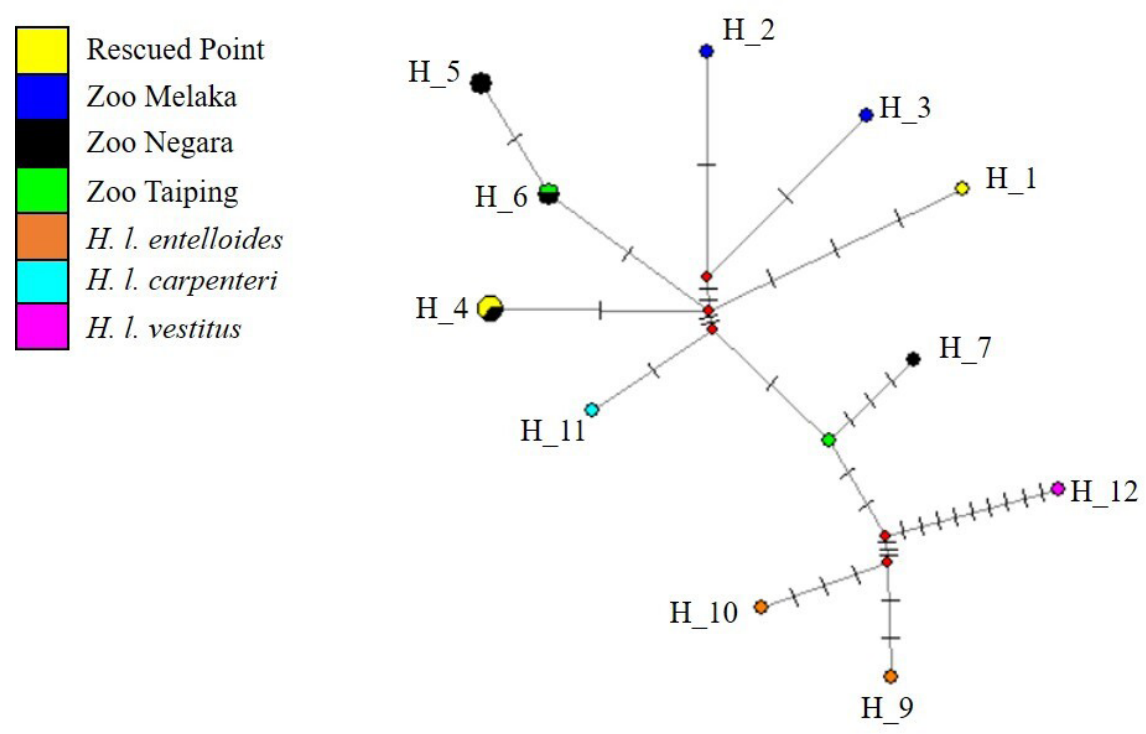

Figure 3: Minimum-spinning network (MSN) illustrating haplotype relationships

\section{Discussion}

Phylogenetic analyses indicated distinct systematic relationships among 12 captive gibbons, reflecting subspecies classification as previously described by Roos et al. (2014). Two individuals from the National Zoo and Taiping Zoo were grouped with $H . l$. carpenteri, confirming their genetic identity as a subspecies from Thailand. This was not surprising, as Woodruff et al. (2005) pointed out, many gibbons may have been traded and exported through Bangkok, Thailand. Presumably, gibbons were brought to Malaysia from Thailand through wildlife trafficking, or animal translocations among zoos. These two individuals may have traveled exceptionally far to reach Malaysia, as their biogeographic distribution covers the regions of East Burma, West Laos, and Northern Thailand. Especially compared to $H$. $l$. carpenteri, which are more restricted to Southeast Burma, Central, and Southern Thailand (Groves, 2001; BrandonJones et al., 2004; Roos et al., 2014). The remaining 10 individuals were suspected to be H. l. lar. This was supported by morphological observations (Figure 4) and information provided by zoo management on their potential origin from Peninsular Malaysia. According to Groves (2001) and Mootnick (2006), the morphological characteristics of $H$. l. lar are: medium brown or dark chocolate brown, in the dark form, as illustrated in Figure 4; compared to $H$. l. carpenteri, which are almost black or brownish charcoal in the dark form. Thus, this morphological variation supported the molecular conclusion of $H$. lar in captivity. Additionally, haplotype and MSN analyses further distinguished the $H$. l. lar clade from $H$. l. carpenteri.

The lar gibbon is classified as endangered, according to IUCN Red List (Brockelman \& Geissmann, 2020). Various threats exist for wild gibbon populations, including habitat loss due to deforestation for agriculture mining, as well as illegal hunting, and pet trading (Thinh et al., 2010). The pet trade is a major cause of the declining numbers in primate populations (Mittermeier et al., 2009). Gibbons are adopted as pets due to their perceived "cuteness" and less threatening nature, compared to the Cercopithecoidea primates, like macaques (Ruslin et al., 2017). Social media plays an important role in the promotion of gibbons as pets, leading to greater demand for exotic primate pets from neighboring countries. This could automatically promote primate 


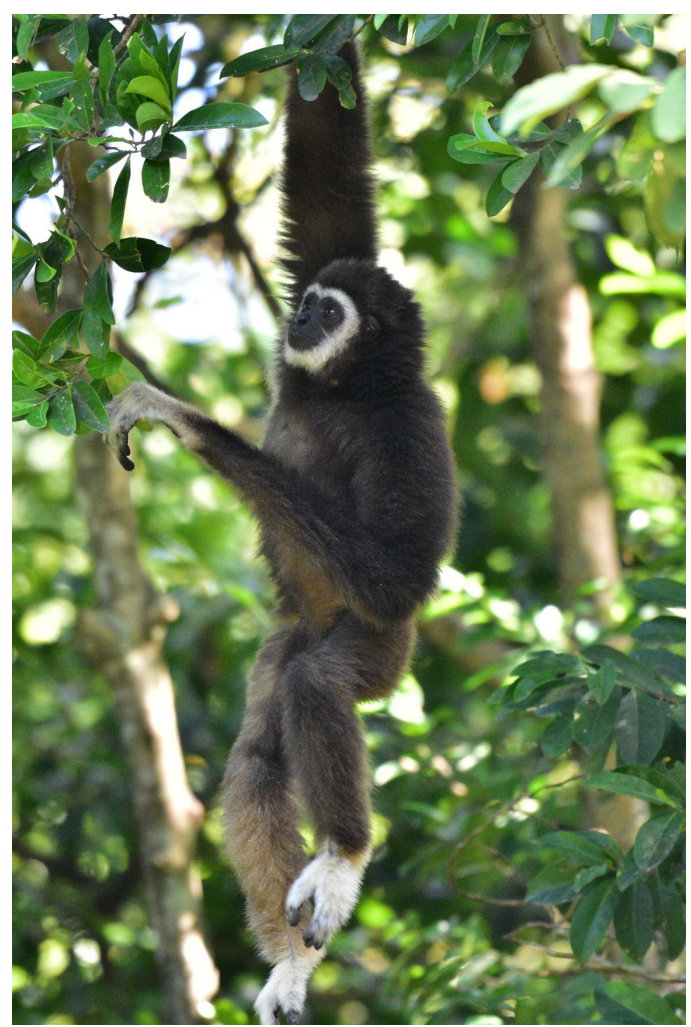

Figure 4: White-handed gibbon from Melaka Zoo trafficking all over Southeast Asia. Primate translocation is one of the main conservation efforts aimed at returning primates to their original habitats. Species identification is therefore crucial, especially in primates kept in captivity as translocation of the primate back to its appropriate region of origin minimizes the impact on gene flow.

Gibbon species identification and taxonomy studies are mostly based on morphological characteristics. However, morphological variation at a subspecies level may be unreliable if origin and parentage information is unclear. Genetic identification is important as only gibbons with clear taxonomic status are permissible for reproduction in zoos or rescue centers, to avoid artificial hybridization (Thinh et al., 2010). Closely related gene pools should be grouped together to reduce outbreeding depression and to maintain genetic traits across generations. Additionally, primate translocation for conservation should be executed according to the closeness of genetic relationships to ensure long-term population survival (Gibbons et al., 1995).

\section{Conclusion}

Identification of white-handed gibbon subspecies in captivity was successfully executed through analysis of the 674 bp Cyt $b$ gene sequences. Twelve captive white-handed gibbons were postulated to belong to the subspecies H. l. lar and $H$. l. carpenteri. While our findings are preliminary, it provided a significant insight on primate genetic identification in captive populations. In the future, additional $H$. lar samples from wild populations should be added for further validation of genetic identity. Additional loci, like the mitochondrial D-loop region and nuclear microsatellites, are among the suggested candidate markers for future investigation. This molecular phylogenetic study significantly contributed to gibbon conservation and captive management.

\section{Acknowledgements}

We are deeply indebted to the Ministry of Energy and Natural Resources and Department of Wildlife and National Parks (DWNP) that provided us research permit (NRE 600-212121 Jld. 7 (29). We also thank the managements of the Zoo Melaka, Zoo Taiping, National Zoo for providing us gibbon fecal genetic samples. We also thank Mr Mohd Ridwan Abd Rahman for his photography contribution at Melaka Zoo. We acknowledged Prof Dr Christian Roos (German Primate Center, Leibniz Institute for Primate Research) for his contribution to improve the phylogenetic analyses. The authors acknowledge Faculty of Science and Technology, Universiti Kebangsaan Malaysia for providing necessary funding, facilities and assistance. This research was supported by grants ERGS/1/2013/STWN10/UKM/02/1, AP2015-004 and UKM-GUP-2017-087. 


\section{References}

Abdul-Latiff, M. A. B., Aifat, N. R., Yaakop, S., \& Md-Zain, B. M. (2017). A noninvasive molecular approach: Exploiting specieslocus-specific per primers in defeating numts and dna cross-contamination of Cercopithecidae DNA. Journal of Animal and Plant Sciences, 27(3), 1015-1023.

Abdul-Latiff, M. A. B., Baharuddin, H., AbdulPatah, P., \& Md-Zain, B. M. (2019). Is Malaysia's banded langur, Presbytis femoralis femoralis actually Presbytis neglectus neglectus? Taxonomic revision with new insights on the radiation history of the Presbytis species group in Southeast Asia. Primates, 60(1), 63-79.

Aifat, N. R., Yaakop, S., \& Md-Zain, B. M. (2016). Optimization of partial Cyt $b$ gene sequence from selected ancient Presbytis museum skin specimens. Malaysian Applied Biology, 45(1), 93-96.

Arnason, U., Gullberg, A., \& Xu, X. (1996). A complete mitochondrial DNA molecule of the white-handed gibbon, Hylobates lar, and comparison among individual mitochondrial genes of all hominoid genera. Hereditas, 124(2), 185-189.

Brandon-Jones, D., Eudey, A. A., Geissmann, T., Groves, C. P., Melnick, D. J., Morales, J. C., Shelkelle, M., \& Stewart, C-B. (2004). Asian Primate Classification. International Journal of Primatology, 25(1), 97-164.

Brockelman, W., \& Geissmann, T. (2020). Hylobates lar. The IUCN Red List of Threatened Species 2020: e.T10548A17967253. Retrieved on 19 August from https://dx.doi. org/10.2305/IUCN.UK.2020-2.RLTS. T10548A17967253.en.

Chan, Y-C., Roos, C., Inoue-Murayama, M., Inoue, E., Shih, C-C., Pei, K. J-C., \& Vigilant, L. (2010). Mitochondrial genome sequences effectively reveal the phylogeny of Hylobates gibbons. PLoS ONE, 8(2), 10.

Chan, Y-C., Roos, C., Inoue-Murayama, M.,
Inoue, E., Shih, C-C., \& Vigilant, L. (2012). A comparative analysis of $\mathrm{Y}$ chromosome and mtDNA phylogenies of the Hylobates gibbons. BMC Evolutionary Biology, 12, 150.

Chatterjee, H. J. (2006). Phylogeny and biogeography of gibbons: A dispersalvicariance analysis. International Journal of Primatology, 27(3), 699-712.

Corbet, G. B., \& Hill, J. E. (1992). The mammals of the Indomalayan Region: A systematic review. Oxford, British: Natural History Museum and Oxford Press.

Garza, J. C., \& Woodruff, D. S. (1992). A phylogenetic study of the gibbons (Hylobates) using DNA obtained noninvasively from hair. Molecular Phylogenetics and Evolution, 1(3), 202210.

Geissmann, T. (2005, June 14). Gibbon Research Lab. http://www.tihohannover.de/gibbons/ main/index html.

Gibbons Jr., E. F., Durrant, B. S., \& Dermarest, J. (1995). Conservation of endangered species in captivity: An interdisciplinary approach. New York, NY: State University of New York Press.

Groves, C. P. (2001). Primate taxonomy. Washington: Smithsonian Institution Press.

Hall, T. A. (1999). BioEdit: A user-friendly biological sequence alignment editor and analysis program for Windows 95/98/NT. Nucleic Acids Symposium Series, 41, 95-98.

Horai, S., Satta, Y., Hayasaka, K., Kondo, R., Inoue, T., Ishida, T., Hayashi, S., \& Takahata, N. (1992). Man's place in Hominoidea revealed by mitochondrial DNA genealogy. Journal of Molecular Evolution, 35(1), 32-43.

Karuppannan, K. V., Aifat, N. R., Mohamed, K. A., Ahmad-Tahir, N. F. D., Nordin, F. M., Yaakop, S., Maldonado, J. E., \& MdZain, B. M. (2019). Genetic variations among selected wild Asian elephant 
populations in Peninsular Malaysia based on mitochondrial D-loop region DNA sequences. Biodiversitas, 20(9), 2494-2502.

Matsudaira, K., \& Ishida, T. (2010). Phylogenetic relationships and divergence dates of the whole mitochondrial genome sequences among three gibbon genera. Molecular Phylogenetics and Evolution, 55(22), 454459.

Matsudaira, K., Reichard, U. H., Malaivijitnond, S., \& Ishida, T. (2013). Molecular evidence for the introgression between Hylobates lar and $H$. pileatus in the wild. Primates, 54, 33-37.

Meyer, T. J., McLain, A. T., Oldenburg, J. M., Faulk, C., Bourgeois, M. G., Conlin, E. M., Mootnick, A. R., de Jong, P. J., Roos, C., Carbone, L., \& Batzer, M. A. (2012). An Alu- based Phylogeny of Gibbons (Hylobatidae). Molecular Biology and Evolution, 29(11), 3441-3450.

Md-Zain, B. M., Lee, S. J., Lakim, M., Ampeng, A., \& Mahani, M. C. (2010). Phylogenetic position of Tarsius bancanus based on partial Cytochrome $b$ DNA sequences. Journal of Biological Sciences, 10(4), 348354.

Md-Zain, B. M., Abid-Kamal, S. N. A., Aifat, N. R., Abdul-Latiff, M. A. B., Mohd-Hashim, A., Ampeng, A., Yaakop, S., \& Samat, A. (2018). Molecular identification of shark fins in Malaysian Borneo's local markets. Biodiversitas, 19(3), 1035-1043.

Md-Zain, B. M., Aifat, N. R., Abdul-Latiff, M. A. B., Mohd-Yusof, N. S., \& Ampeng, A. (2019). Molecular systematic position of the Sarawak Malay Badger, Mydaus javanensis. Malaysian Applied Biology, 48(3), 125-132.

Mittermeier, R. A., Wallis, J., Rylands, A. B., Ganzhorn, J. U., Oates, J. F., Williamson, E. A., Palacios, E., Heymann, E. W., Kierulff, M. C. M., Long Yongcheng, Supriatna, J., Roos, C., Walker, S., Cortés-Ortiz, L., \& Schwitzer, C. (Eds.). (2009). Primates in peril: The world's 25 most endangered primates 2008-2010. Arlington, VA: IUCN/Species Survival Commission (SSC) Primate Specialist Group (PSG), International Primatological Society (IPS), and Conservation International (CI).

Mohd-Yusof, N. S., Juliana, S., Md-Nor, S., \& Md-Zain, B. M. (2020). Haplotype and network analysis of island flying fox (Pteropus hypomelanus) using D-loop region of mitochondrial DNA to confirm subspecies designation. Mammal Research, 65, 375-385.

Mootnick, A. R. (2006). Gibbon (Hylobatidae) species identification recommended for rescue or breeding centers. Primate Conservation, 21, 103-138.

Roos, C., \& Geissmann, T. (2001). Molecular phylogeny of the major hylobatid divisions. Molecular Phylogenetics and Evolution, 19(3), 486-494.

Roos, C., Boonratana, R., Supriatna, J., Fellowes, J. R., Groves, C. P., Nash, S. D., Rylands, A. B., \& Mittermeier, R. A. (2014). An updated taxonomy and conversation status review of Asian primates. Asian Primates Journal, 4(1), 2-38.

Rosli, M. K., Zamzuraida, A. S., Syed-Shabtar, S. M. F., Mahani, M. C., Abas-Mazni, O., \& Md-Zain, B. M. (2011). Optimization of PCR conditions to amplify Cyt $b, \mathrm{COI}$ and 12S rRNA gene fragments of Malayan Gaur (Bos gaurus hubbacki) mtDNA. Genetics and Molecular Research, 10(4), 2554-2568.

Ruslin, F., Azmi, M. A., Matsuda, I., Amir, R., \& Md-Zain, B. M. (2017). Monkey school: Training phases for coconut-picking macaques (Macaca nemestrina). Malayan Nat J, 69, 301-306.

Takacs, Z., Morales, J. C., Geissmann, T., \& Melnick, D. J. (2005). A complete specieslevel phylogeny of the Hylobatidae based on mitochondrial ND3-ND4 gene sequences. Molecular Phylogenetics and Evolution, 36(3), 456-467. 
Tamura, K., Stecher, G., Peterson, D., Filipski, A., \& Kumar, S. (2013). MEGA 6: Molecular Evolutionary Genetics Analysis version 6.0. Molecular Biology and Evolution, 30(12), 2725-2729.

Thinh, V. N., Mootnick, A. R., Geissmann, T., Li, M., Zeigler, T., Agil, M., Moisson, P., Nadler, T. Walter, L., \& Roos, C. (2010). Mitochondrial evidence for multiple radiations in the evolutionary history of small apes. BMC Evolutionary Biology, 10(1), 74 .

Veeramah, K. R., Woerner, A. E., Johnstone, L., Gut, I., Gut, M., Marques-Bonet, T., Carbone, L., Wall, J. D., \& Hammer,
M. F. (2015). Examining phylogenetic relationships among gibbon genera using whole genome sequence data using an approximate Bayesian computation approach. Genetics, 200, 295-308.

Woodruff, D. S., Monda, K., \& Simmons, R. E. (2005). Mitochondrial DNA sequence variation and subspecific taxonomy in the white-handed gibbon, Hylobates lar. Nat Hist J Chulalongkorn Univ, 1, 71-78.

Zainudin, R., Shukor M. N., Norhayati, A., Md-Zain, B. M., \& Mustafa, A. R. (2010). Genetic structure of Hylarana erythraea (Amphibia: Anura: Ranidae) from Malaysia. Zoological Studies, 49(5), 688-702. 